\title{
Popular Media in the Culture of English-Canadian Children in the Twentieth Century ${ }^{1}$
}

\author{
Neil Sutherland
}

In 1901, the Canadian naturalist writer Ernest Thompson Seton lectured in Toronto. A mother reported she "took my children to hear him but hear him we did not! They had allowed the Public School children in for ten cents (we had to pay 50cts) \& they behaved so badly \& made so much noise that we could not hear one word \& what was more disgusting they spit on us from the gallery."2

$$
* * *
$$

In Winnipeg, just after the Great War, James H. Gray was "infected by my friend Gordon Main...He was, he said, building a wireless set on which he would be able to hear music being broadcast on Station KDKA in Pittsburgh, Pennsylvania. Within the hour I had absorbed all of Gordon's newly acquired expertise...With our homemade crystal sets we not only astounded our parents...but we also flabbergasted the neighbours with the snatches of music coaxed from our sets."3

1 I gave an earlier version of this paper to the European Social Science History Conference in Amsterdam in March, 1998. Small portions of it have been drawn, much recast, from my Growing Up: Childhood in English Canada from the Great War to the Age of Television (Toronto: University of Toronto Press, 1997).

2 Winnifred Woolryche, Toronto, to Grace, 26 Mar. 1901. Letter in the possession of the writer.

3 James H. Gray, The Boy from Winnipeg (Toronto: Macmillan, 1970), 14-15. The first commercial radio broadcasts in Canada took place in 1919. Sandy Stewart, A Pictorial History of Radio in Canada (Toronto: Gage, 1975), 29-30.

(c) Historical Studies in Education/Revue d'histoire de l'éducation 14, 1 ( 2002): 1-34 
In 1956, 12-year-old Frank McEnaney was in grade six in a Toronto public school. He recounted that "one day my best friend...ran up to a bunch of us, more excited than we had ever seen him. He'd seen this guy on TV.” When McEnaney's gang came to watch the newly discovered singer on television, "one thing was clear to every kid in that room: This was no crooner. This was something different entirely. This felt...right." As each of the singer's new records appeared, "We would...play it over and over and over again. Elvis! Elvis! Elvis! Each one seemed more amazing than the one before. Hound Dog, Blue Suede Shoes, Heartbreak Hotel, Don't Be Cruel, All Shook Up.” Then, "Elvis was coming to Toronto! My father, in an act of generosity for which I will always be grateful, stopped off at Maple Leaf Gardens on his way to work and purchased two tickets. Elvis Presley was coming to town, and I-I and my best friend, Jerry-were going to get to see him."4

In January, 1998, three “very angry girls”-Sherry Kennedy, Laura Gibbons, and Katie Gibbons-wrote to the Vancouver Sun that theatre staff "wouldn't let us in Scream 2, even with our parents' permission... We are 14, can't drive and have nothing to do but see movies to be entertained, and if we can't see movies that are good, what is there to do?... Young adults like us want thrills, and scary movies are as thrilling as we can get."5

As soon as the video version of Star Wars Episode I: the Phantom Menace appeared, Susan Mayes reported, she "discovered my 10-year-old daughter camped in front of the VCR. Scene by scene, Annie was freeze-framing her way through...to check

4 Toronto Globe and Mail, 16 Aug. 1997, C1.

5 Vancouver Sun, 3 Jan. 1998, D2. 
rumours (false) of a walk-through" by the minor character Boba Flett whom fans brought "back to life" and made a hero "in the alternate universe of novels and short stories that surround the film.” Annie also wanted to read these spinoff stories. ${ }^{6}$

As these opening quotations demonstrate, from peep shows and Charlie Chaplin one-reelers at the nickelodeon to the Saturday cartoons on television and game sites and chat rooms on the internet, children enthusiastically and actively welcomed the new. And if there was enormous change in the media themselves over the century, there was also considerable continuity in kids' response to them. Their "scripts" reveal a persistent pattern repeating itself from child to child and from year to year over most of the century. From their reading and re-reading and discussing such favourites as the Anne books, to their enthusiastic footpounding during chases in one-reelers, to their deconstruction (and reconstruction) of Star Wars in the myth-making around the character Boba Flett, children entered into an active relationship with what they heard and saw. And, as what follows will show, both their gender and their class affected their response, although in the case of gender, perhaps not to the degree popular notions might lead one to expect.

Children's relations with media were not isolated from their wider world. From classification schemes, censorship, and curfews, to the v-chip, parents, teachers, and other adults have tried to regulate and control their youngsters' enjoyment of all media. In their earliest years, the sounds youngsters heard and the images they saw were in the control of others. Over the years of childhood, however, children tried to establish an independent relationship with media and, on their own or in co-operation with siblings and peers, enter into the role that media played in the culture of childhood. Advertisers recognized the market potential

6 Susan Mayes, “The Tao of Boba Flett,” Vancouver Sun, 3 June 2000, D13. 
in youthful interests. From newspaper advertisements for "you, too, can be a magician” kits, through "Quint” dolls, to the creation of such children's cartoons, centred around expensive toys, as "Pokemon" and the "Power Rangers," business has tied merchandise to children's entertainment.

And the past, in entertainment, never goes away. Children still read such classics as the Anne books and Huckleberry Finn and can watch television programmes, such as the "Flintstones" and the "Three Stooges," and movies, such as Bambi, that captivated their parents and grandparents. Modern media are also increasingly self-referential. As Kenneth Tynan shrewdly observed, "Novels, plays, and films are filled with references to, quotations from, parodies of-old movies. They dominate the cultural subconscious because we absorb them in our formative years... and we see them again on TV when we grow up."7

Although written in light of the considerable research in Canada and elsewhere on the supposed effects of media on children, and the supposed need for control and censorship of young people's access to them, this paper gives its attention to youngsters' own perception of both domestic and public media and their relationship to them. ${ }^{8}$ Its data are the recollections of Canadians born in the period from the last years of the nineteenth century up to the final ones of the twentieth. I collected my data from taking oral histories, from interviews recorded in newspapers and magazines, and from memoirs, autobiographies, and biographies. I focus on the childhood years; that is, on those years from children's earliest memories to early adolescence.

One cannot rely on the exact factual details of such memories. One can, however, usually accept the emotional

7 Kenneth Tynan's journals, 19 Oct. 1975, as quoted in The New Yorker, 14 Aug. 2000, 64.

8 Canadian research on media and young people is listed in Neil Sutherland, Jean Barman, and Linda L. Hale, eds., History of Canadian Childhood and Youth: A Bibliography (Westport, CN: Greenwood, 1993) and Sutherland, Barman, and Hale, eds., Contemporary Canadian Childhood and Youth: A Bibliography (Westport CT: Greenwood, 1993). The latter volume, for example, lists over 120 items under the heading "Media Impact." Recent psychological and social science research on children and television is summarized in Maire Messenger Davies, 'Dear BBC:' Children, Television Storytelling and the Public Sphere (Cambridge: Cambridge University Press, 2001). 
dimension embodied in them. We can, for example, believe that Frank McEnaney and his friends were, indeed, fascinated by Elvis Presley and that his warmly recalled gratitude to his father was deeply felt. On the other hand, much of what is written these days about memory by historians and others suggests there is an ironic distance amongst memory, the topic remembered, and those doing the remembering. Since most of those cited in this paper are not reflective professionals, irony is not amongst the historiographical problems they raise. ${ }^{9}$ Even those now aware of the irony tend not to apply it to their own childhood experiences. Thus, Johanna Schneller wrote of her fascination with Julie Andrews as an "ideal mum." In her role as Maria, "for those of us who saw it when we were kids — un-ironic, non-judgemental-The Sound of Music got its hooks in, and held. We wanted to be Julie...At the same time we wanted to be cared for by Julie..."10

While the paper deals with the whole of the twentieth century, my conclusions are more tentative with regard to its later years than to the earlier ones. More data, and especially those recorded in as yet unwritten autobiographies and memoirs, will enable a later generation of historians to come to more certain conclusions. ${ }^{11}$

II

Some media are as old as the race itself. From the moment they are born children are immersed in sound. Sounds, and especially speaking and singing voices, swirl around them, forming the context in which they begin to construct their growing sense of themselves. Some of this sound is aimed at them; they hear prayers, lullabies, songs, stories, and conversation directed at or

9 I discuss the reliability and other aspects of memories of childhood in Sutherland, Growing Up, chap. 1.

10 Toronto Globe and Mail, 3 Feb. 2001, R1-2.

11 As later pages will show, most of the autobiographies and biographies of those born after mid-century that I consulted are of media "personalities.” Their scripts may not always be representative of their cohort. 
about them. Over the century, recorded music and words, radios, televisions, and videos came to merge their sounds into the background cacophony to childhood experiences.

Since family culture is an oral culture, the sway of the human voice persists through childhood. From it, children took on the history and lore of their families, and heard myths, legends, and tall stories that often triggered their imaginations. They also acquired attitudes on gender, class, race, and nationality, and on local and national events. In her family's farmhouse home in Ontario before the Great War, Jessie Beattie “was never weary of hearing stories”; she drew her "small rocking chair to a half-hidden position between my father's armchair and the oval table centred by a large lamp and littered with papers and books" to listen to her parents talk with their visitors. ${ }^{12}$ At about the same time, in the upper Fraser Valley near Hope, BC, self-described half-breed Henry Pennier related that "at night," his step-father's father "used to tell us long stories of the past. Especially in the long winter evenings with us sitting around the wood stove to stay warm we listened to him tell us about brave Indian warriors and spooky dead spirits and beautiful Indian maidens and I guess that was when I started to be proud I was a Indian or at least part of one."13

When he was about five or six towards the end of that war, Joe Zuken's family "spent many fascinating evenings in the winter time in the kitchen" of their North Winnipeg home "listening to these landsleit [people from the same village in Eastern Europe] reminisce about the things they had left behind and the struggles that some of them had gone through." 14 Growing up in the late 1930s and 1940s in the isolated Newfoundland fishing village of Arnold's Cove, Ray Guy recalled: "Night after night the old men sat around lamp-lit kitchens and repeated their repertoire of anecdotes, half of which they'd learned verbatim from their own fathers and grandfathers.” On his first visit to St. John's in 1948,

12 Jessie L. Beattie, A Season Past: Reminiscences of a Rural Canadian Childhood (Toronto: McClelland and Stewart, 1969), 50-51.

13 Henry Pennier, Chiefly Indian: The Warm and Witty Story of a British Columbia Half Breed Logger, ed. Herbert L. McDonald (West Vancouver: Graydonald, 1972), 17-18.

14 Doug Smith, Joe Zuken: Citizen and Socialist (Toronto: Lorimer, 1990), 12. 
Guy expected to see Water Street as “an almost medieval nightmare of whipping posts, cat-o'-nine-tails, stocks, dunking stools, pirates, gallows and gibbets...And the Whirlygig, most terrible because I couldn't even imagine what it was 'they used to put young boys, your age, into for stealing a loaf of bread'.”15

Most children participated in family discourse. Some employed their own voices as weapons. Lee Maracle, born in 1950, reported that when she was “three years old I still didn't talk. My parents were worried about it and took me to see a doctor several in fact...My folks were always arguing about me. I was often left with a woman...because dad kept beating up on me and mom didn't like it...My silence lasted another year. Then one day mom caught me talking to Roger [her brother who was eleven months older], with whom I was very close, and after that the jig was up. I started talking a little with my parents, but not very much. I didn't like big people. I thought they were interesting, but not people I wanted to talk to.”16

The sound of music was central to the life of many families. "My mother loved music," reported Angus MacLean of his family in Prince Edward Island early in the twentieth century. "She sang in the church choir, and when she had a rare free moment, she used to play hymns and favourite songs in the parlour on her beloved reed organ, an instrument she had brought with her when she came to the house as a bride." MacLean and his sister Margaret played together "and sang together around the reed organ."17 In the 1930s Helen (Masse) Sigurdson’s Franco-Manitoba home contained a player piano, an organ, and a gramophone. She spent "many hours listening to the seventy-eight-inch records of the time. I enjoyed 'Rubber Dolly,' 'The Red River Valley,' the 'Yellow Rose of Texas,' and other favourites." ${ }^{18}$ John Norris, who sang in school and church choirs in Nelson, BC, remembers "the extraordinary

15 Ray Guy, “Water Street's ebb and flow,” Canadian Geographic, 1999 Annual, 59.

16 Lee Maracle, Bobbi Lee: Indian Rebel (Toronto: Women's Press, 1990), 23.

17 J Angus MacLean, Making It Home: Memoirs of J. Angus MacLean (Charlottetown: Ragweed, 1998).

18 Helen Sigurdson, I Wanted You to Know (Winnipeg: JP \& Associates, 1994), 25. 
feeling of blessedness that sometimes overcame me on dark winter afternoons as we stood in the music room practicing...carols.” ${ }^{19}$

Even as phonograph records, radio, television, and other forms of recorded music brought professionally created music into the home, many families continued to perform their own. Although his grandfather first taught Stompin’ Tom Connors to sing, his teenage "mother was my greatest musical influence. Names like Wilf Carter and Hank Snow were household words at our place, and my mother used to know the words to most of the songs...I can still picture her standing in front of a mirror, wearing one of Grampy's old hats and singing 'I'm an Old Cowhand from the Rio Grande.' Pausing for a moment to reflect, she turned and went to the kitchen....and now there was a more satisfactory performance. She was strumming on the broom!”20 As did Connors himself, some families, including the Rankin children in Cape Breton and the McGarrigles of Montreal, turned family music-making into professional careers.

Music could leaven harsh upbringings. There is not much happiness in Rita MacNeil's account of her childhood. Her parents argued, sometimes fought each other, and occasionally drank heavily. She was sexually abused by a great-uncle, and, until she had corrective surgery, teased about her upper lip. Nonetheless, some lightness shows through when she discusses the role that music played in her life. "I was very fond of the old piano...I discovered how much music meant to me then, bubbling up from deep inside...I took up singing and poured my soul into it." MacNeil listened to the radio with her mother. On evenings in December they "listened to Christmas carols sung by a choir...It is one of my most treasured memories, lying in bed with my mother as the choir sang 'O Holy Night'." After the family moved from Big Pond, on Cape Breton, to Toronto, "I'd sit inside the dark apartment and listen to the radio...,singing along to an Elvis Presley song, like 'Love Me Tender,' or 'Blue Suede Shoes,'

19 John Norris, Wo Lee Stories: Memories of a Childhood in Nelson, BC (New Denver: Twa Corbies, 1997), 53.

20 Stompin' Tom Connors, Stompin' Tom: Before the Fame (Toronto: Penguin, 1995), 13. 
rocking back and forth on my parents' bed when they were at work."21

Children took special delight in letters that connected separated families. In Canada with her mother and brother during the Second World War, Marianne Hollanby considers letters from her father in England as amongst her "most treasured possessions."22 In 1957, when she was seven years old, welfare workers sent Mary Lawrence and two of her siblings from their home on a reserve near Vernon, BC, to the residential school in Cranbrook. They often received a one-page letter from their aunt Yvonne "telling us that Grandma, Bill, James and she were all fine. She never mentioned Mom but ended her letter with 'Write soon, Always, Yvonne.' I never got a letter from Mom...The letters I received from Yvonne I treasured. I can't recall what they said, probably just that everyone was fine. It wasn't so much what the letter said, it was just that someone had taken the time to write...I had no idea when we would be able to go home.”23

Reading was often an oral medium, especially for young children. Many parents regularly read or told their youngsters bedtime stories. People who grew up in the 1920s, '30s, and '40s recalled being read the Thornton $W$. Burgess stories that appeared in many daily newspapers. Others remember hearing parents or teachers reading "Hiawatha," Robinson Crusoe, Beautiful Joe, The Water Babies, Westward Ho!, Noddy, the novels of Sir Walter Scott, Charles Dickens, and Robert Munsch. Young children had favourites that they liked to hear again and again. One youngster in the 1930s loved to hear the stereotypical Little Back Sambo over and over again. Like many young children, he was never absolutely certain that the story would end just as it had on other readings and was always relieved when the tiger again turned into butter for the pancakes.

21 Rita MacNeil with Anne Simpson, On a Personal Note (Toronto: Key Porter, 1998), 19, 41, 60.

22 Marianne Burwood Hollanby, I Remember in Colour (London: M.B. Hollanby, 1999), facing p. 17.

23 Mary Lawrence, My People, Myself (Prince George, B.C.: Caitlin Press, 1996), 23-25. 
Children remember when they began to read for themselves. Many people fondly recall the adventures of Dick and Jane, not, obviously for the content but because they, themselves, read about them. Earl Baity grew up in a pioneering home in north central British Columbia. His rural school had no library but when his teacher, "an exceptionally good reader," started to read Treasure Island he found "it something of a surprise when I learned that reading could be fun.” Baity had to quit school at about fourteen to look after, entirely on his own, the family horses kept at a remote location. His teacher, Jean McClarty, "managed to keep a trickle of books coming up to me. Huckleberry Finn; Kidnapped; Oliver Twist and The Man From Glengarry all found their way up that winding sleigh road and into that lonely cabin in the wilderness." ${ }^{24}$

Children wove what they read into games and pastimes. Huckleberry Finn prompted many children into building rafts on nearby bodies of water, although rarely to the extent taken by "Fee" Hellman. "If Huckleberry Finn and Tom Sawyer could do it," reported Hellman, "so could we." In the late 1920s, and after two attempts, one of which was nearly fatal, Hellman and a friend made a raft and rode it some miles down the Kootenay River, when the "fresh spring foliage was at its brightest and best, the light breeze loaded with fragrance.” They grounded "our craft in a backwater, clambered to firm ground, and then faced the long journey home on foot."25

For some, reading became a practical skill, one to be employed at school, or to find information on topics that interested them. They read Mechanix Illustrated, The Books of Knowledge, encyclopaedias, books describing natural history topics such as the ever-popular dinosaurs, magazines and catalogues for details of the latest fashions, and stories about sport, film, and pop stars in movie, sports, and "teen” magazines. Indeed, many children did not go beyond using reading as practical skill, for use at school and later in the wider world. Certainly, whether for a lack of books or

24 Earl S. Baity, I Remember Chilako (Prince George: Prince George Printers, 1978), 71-72.

25 Ernest F. “Fee” Hellman, Kootenay Country: One Man's Life in the Canadian Rockies (Bothwell, WA: Alaska Northwest Books, 1990), 9, 13. 
of interest, recreational reading was not a universal practice amongst Canadian youngsters. My informal survey of most of the Canadian biographies and autobiographies in the large popular biography section of the Vancouver Public Library found only about half of their authors or subjects mentioned reading, or favourite books of childhood.

Sensational newspaper stories attracted youthful attention. When he was nine, in 1922, Duke DeCoursey "became fascinated for the first time with the written word." A local murder was Free Press Prairie Farmer. Each Saturday, DeCoursey “rode my saddle pony, Katy,... six miles" to pick up the paper, "read the murder trial and hanging proceedings carefully, then returned home to contemplate the following week's edition."26 In British Columbia in the 1940s, children followed and avidly discussed the widely reported trial of a rapist and murderer. ${ }^{27}$

Other children read mostly for their own pleasure. Once Phyllis Grosskurth "could read by myself, I developed strong likes and dislikes. I didn't like animal stories, but I devoured the whole Bobbsey Twins series,... But generally I was addicted to stories of suffering orphans. There was Cedric, Little Lord Fauntleroy...Elsie Dinsmore was even more of a tearjerker...I skipped all the religious bits...in order to learn whether Elsie's father ever appreciated her true worth...My all-time favourite was handed to me on my tenth birthday by Mother; she had loved L.M. Montgomery's The Story Girl when she was young." None of Montgomery's other girl protagonists, such as Anne or Emily, "was a patch on the storytelling Sara Stanley, another orphan, who holds all the children on the farm transfixed with her tales...I must have read The Story Girl a hundred times."28

In Jackson's Arm, Newfoundland, Reg Sparks found “in those summer 'days that were as long as twenty days are now,' the

26 Duke DeCoursey, All in a Lifetime: Newspapering and Other Pioneer Adventures (Squamish, BC: Parkview Publishing, n.d.), 32-33.

27 I did not understand oblique references to this case that came up in at least three interviews until I read Howard White, "Duchaume: Anatomy of a Legend,” Raincoast Chronicles 9 (1979): 51-57.

28 Phyllis Grosskurth, Elusive Subject: A Biographer's Life (Toronto: Macfarlane, Walter \& Ross, 1999), 20-21. 
magic that lay between the covers of a book dissolved all barriers of time and space and swept me away with the clouds to all the corners of the earth and far beyond. To the stars with Flammarion, into the lands of enchantment with the brothers Grimm and into the world of mythology with Bullfinch; but the greatest joy was to discover that there was no limit to the world of books."29 Turn-ofthe-new- century children have been captivated by the series of novels featuring teen-aged wizard Harry Potter. Nine-year-old Victorian Breanna Francis told a reporter that “I hadn't read much before but, at Christmas, my grandmother bought me the first book and I've been reading a lot.” A twelve-year old girl reported that she had read one of the series seven times. ${ }^{30}$

The number of widely read books for children increased enormously in the latter half of the century. Nonetheless, the popularity of certain classics persisted. The range was nicely revealed when, in one of many articles marking the publication of a new Harry Potter book, five Canadian writers of books for children described who had been favourite authors of their youth. Marie-Louise Gay noted Winnie the Pooh, the Chronicles of Narnia, Tolkien's books, Watership Down, by Richard Adams, and "a lot of classic science fiction, including John Wyndham's The Day of the Triffids.” Janet Lunn, who "loved fantasy and historical novels," listed the Bobbsey Twins, Nancy Drew, Louisa May Alcott, Lucy Maud Montgomery, Robert Louis Stevenson's A Child's Garden of Verses, and Edith Nesbit's The Treasure Seekers. Jean Little's “favourite was Frances Burnett's The Secret Garden, without question.” She also liked Montgomery's books. Robert Munsch selected The 500 Hats of Bartholomew Cubbins, by Dr. Seuss. When Munsch "started reading it was Lassie Come Home. I was a nerd-I went to the library every day in the summer when everybody else was playing baseball.” Richard Scrimger selected Narnia. His "hero was Freddy the Pig, a detective." Science fiction was "vital” to him. He "never read Anne of Green

29 R. F. Sparkes, The Winds Softly Sigh (St. John's: Breakwater, 1981), 34-35.

30 Victoria Times Colonist, 7 July 2000, 5. 
Gables or Little Women" but "liked the Hornblower series by C.S. Forester." ${ }^{11}$

For some children, reading provided a private place, or even a refuge to which they could escape from loneliness, illness, real or imagined wrongs, or even abuse. Gertrude Story was "crazy about Anne of Green Gables...[because] Anne was as misfortunate as I was, and so we connected and were kindred spirits or anything else she wanted to say we were..." ${ }^{\text {"32 }}$ Takashima reported reading in her home in the New Denver internment camp. "The small candle casts an orange glow on my book. I am reading about Marco Polo again. My mind leaves our house...I feel like a princess being rescued by a brave, dark Tartar." ${ }^{33}$ When self-described gay activist Jim Egan was "around twelve to fourteen years old," in the early 1930s, he bought copies of his "favorite English boys' magazines," The Magnet, The Gem, and The Boy's Own Annual. "Álthough there was never a whisper of homosexuality in them, looking back now it seems that the stories... were charged with homoerotic implications...I read these stories religiously. The schoolboys who were depicted in them were probably sixteen or seventeen years old, and were shown in line drawings of idealized youthful beauty. I suppose I projected a degree of friendship that wasn't there... [but] it seems to me that it would be easy to interpret the stories that way. And, believe me, my imagination went wild!"34

Daily and weekly newspapers sometimes catered to both the practical and imaginative characteristics of youthful readers. They ran daily and weekly comic strips-often called "the funnies" - which attracted a wide readership amongst adults as well as children. In the early 1930s, Harvey Kirck lived in the hamlet of Uno Park in northeastern Ontario. "Each weekend it was my job to pick up the [Toronto] Star Weekly and the first thing I'd do was check to make sure that the funnies were there, tucked into the

31 National Post, 8 July 2000, W12.

32 Gertrude Story, The Last House on Main Street (Saskatoon: Thistledown, 1998), 98.

33 Takashima, A Child in a Prison Camp (Montreal: Tundra 1971), chap. 3.

34 Jim Egan, Challenging the Conspiracy of Silence: My Life as a Canadian Gay Activist, comp. and ed. Donald W. McLeod (Toronto: Homewood Books, 1998), 18. 
glossy lithograph section: Tarzan the Ape Man, Maggie and Jiggs, Bronco Bill, Mandrake the Magician, Popeye, Dick Tracy, and Jimmy Frise and Greg Clark's 'Bird's Eye Centre.' What finer way is there for a young fellow to spend a Saturday afternoon than to sit with his father and mother reading the funnies?"35

Some newspapers also provided an outlet for those who wanted to express themselves in print. Norah Lewis' collection of children's letters drawn from weekly newspapers, most directed at rural audiences, demonstrates the breadth of youthful interests and the very considerable skill with which they described them. ${ }^{36}$ Early in the century, Gilean Douglas contributed to the Toronto News. Much later, she wrote, "I can smell that newsprint now... The day my letter was in, and a poem, I went flying down the walk to meet Daddy with the paper in my hand." 37 Claire Drainie Taylor wrote: "The Regina Leader Post may, or may not, have been a good newspaper, but it did feature a Saturday 'Torchbearers' page all written by children, which I loved. I read it religiously and...got up the nerve to mail in a few poems and letters of my own...and to my great delight the letter was published."38

Comics also appeared in the form of comic books. Mordecai Richler argued that, for his generation, "there was nothing quite like comic books." ${ }^{39}$ And later cohorts agreed. When Paul Jay was in grade five, "the boys all wanted to be one hero: Wolverine...a mutant superhero from Canada with acute animal senses, a nasty temper, and retractable, razor-sharp metal claws that he uses for gouging, slashing, and grappling with evildoers...[M]y friends and I embraced Wolverine as our own. I worked with my brothers at

35 Harvey Kirck with Wade Rowland, Nobody Calls Me Mister Kirck (Toronto: Collins, 1985), 7.

36 Norah L. Lewis, ed., "I want to join your club”: Letters from Rural Children, 19001920 (Waterloo: Wilfrid Laurier University Press, 1996).

37 Andrea Lebowitz and Gillian Milton, Gilean Douglas: Writing Nature, Finding Home (Victoria: Sono Nis, 1999), 21.

38 Claire Drainie Taylor, The Surprise of My Life (Waterloo, Ontario: Wilfrid Laurier University Press, 1998). Lloyd Person also described the pleasure he derived from the same feature. See Lloyd H. Person, No Foot in Heaven (Saskatoon: Western Producer, 1978), 5-6.

39 Mordecai Richler, “The Great Comic Book Heroes,” in Hunting Tigers Under Glass: Essays and Reports (London: Panther, 1971), 78-79. 
fashioning Wolverine-style claws out of tinfoil. (The claws were, to our disappointment, more ornamental than utilitarian.)...Wolverine represented how we wanted to see ourselves-not polite or retiring, but tough and not to be trifled with. His northern roots showed through when he was out of costume, quaffing beer or chopping wood in a plaid shirt, toque and mutton chopped..."40

Contrary to gendered expectations and stereotypes, girls also employed comic books to envision themselves in active, adventurous roles. Poet Gwendolyn MacEwen loved comic books. She remembered "with a mixture of humour and terror" that a local druggist caught her stealing the latest issue of Wonder Women "and chased her through the icy streets of Winnipeg." MacEwen was also caught up by the Marvel family and knew "all the key words to utter to bring about the thundering transformation." 41 Marvel comics also stimulated in MacEwen dreams of flying: "You know you can fly, the way they do, straight out, with the arms forward and poised like upside-down divers..."42 "All one spring and summer," Helen Porter and her cousin Dot "had a running series of Flash Gordon adventures, during which we acted out the escapades of Flash and Dale...We carefully watched the serials at the Capitol Theatre and read the comic books, adapting them all to the South Side. The big rope swing in Dot's garden was the place for this, for when we swung high it was not too difficult to imagine ourselves in a space ship."43 Simone Blais, dressed as Super-woman, "was a hero...I would take a running start towards the three stairs into our sunken living room, where I would take a flying leap. One day, however, I landed wrong, and ended up in the hospital emergency room with a broken arm...No longer invincible, I watched her on TV, wishing I could fly."44

40 Paul Jay, "Wolverine,” Saturday Night, May 1999, 24. Wolverine comics began to appear in the early 1970 s.

41 Rosemary Sullivan, Shadow Maker: The Life of Gwendolyn MacEwen (Toronto: Harper Collins, 1995), 37-41.

42 Ibid., 40.

43 Helen Porter, Below the Bridge: Memories of the South Side of St. John's (St. John's: Breakwater, 1979), 84.

44 Vancouver Sun, 1 May 1999, A22. 
Particularly in the early years of the century, many youngsters found reading materials very hard to come by. Many families, even amongst those who could afford them, had no books other than a bible, a catechism, and other religious material. Jessie Mifflin, who grew up in Bonavista, Newfoundland, explained "books were regarded as a luxury," and quoted a neighbour's comment on the many books in her house: "it seemed an awful waste of money to buy them." 45 Those whose homes lacked books had to borrow from friends, or a school or public library. School and classroom libraries, such as the one noted above by Earle Baity, often depended on the generosity of teachers for their generally meagre collections. Denominational publications, such as weekly Sunday school papers and the United Church's popular magazines Canadian Girl and Canadian Boy, tried to provide wholesome reading for youngsters.

Even after the Second World War, there still weren't a lot of books available in country schools. Linda Turk reported, "I started Grade 1 in 1960, and still feel a thrill of excitement at the thought of the library truck, bringing us a new set of books to enjoy for two or three months. Fifty books and a painting; that was the allowance for a school with twenty-some students. I don't remember an encyclopedia at any of the three public schools I attended." ${ }^{\text {"46 }}$

Children in larger towns and cities often had children's collections in their public libraries. When Dorothy Jean Harris returned to Canada early in the Second World War, "there was the St. Catharine's Public Library, with a basement devoted entirely to children's books. What a treasure trove! I think it was reading The Count of Monte Christo non-stop that led to my first pair of glasses." ${ }^{\prime 7}$ Mary Pratt's grandmother took her to the Legislative Library in Fredericton, and arranged for her to have a library card. There, the librarian "chirped directions as to what books were

45 Jessie Mifflin, A Collection of Memories by Jessie Mifflin (St John’s: Harry Cuff, 1989), 4.

46 Linda Turk, Thunder Bay Chronicle-Journal, 9 Jan. 2000, C1.

47 Dorothy Joan Harris, "Most people would find it hard to pinpoint their earliest memory," in Too Young to Fight: Memories from Our Youth During World War II, ed. Priscilla Galloway (Toronto: Stoddart, 1999), 51. 
suitable for children. When she found Beth and me looking for the wicked bits in adult books, she'd haul us away from Forever Amber or The Sheik and lead us to the great volumes of Audubon lithographs. We were not only allowed but encouraged to turn the pages, using two hands under each page."

Some parents controlled both what might be read and when reading might be done. Parents in the early years of the century were particularly concerned about the malign influence of "penny dreadfuls" and "dime novels." "49 In the early 1950s, publication in the United States of Dr. Fredric Wertham's Seduction of the Innocent, an attack on so-called crime comics, prompted Senator Estes Kefauver of Tennessee to conduct Senate hearings on the topic. $^{50}$ The fuss spilled over into Canada, where, as Mona Gleason has shown, Progressive Conservative Member of Parliament E. Davie Fulton campaigned successfully for legislation-still in place-controlling crime comics. ${ }^{51}$ The strength of the furore here is indicated by the fact that Parliament passed a private member's bill introduced by a member of the opposition.

Over the whole of the century some people have tried to restrict the sorts of books available for children in school and public libraries. In the 1990s in British Columbia, some parents and the school board in the Surrey school district restricted the use of reading and school library materials dealing with families that

48 Mary Pratt, A Personal Calligraphy (Fredericton: Goose Lane, 2000), 51.

49 Turn-of-the-century concern about unsuitable books for children is discussed in Neil Sutherland, Children in English-Canadian Society: Framing the Twentieth Century Consensus (Reprint: Waterloo, Ontario: Wilfrid Laurier University Press, 2000), 19-21. 50 New York: Kennikat Press, 1954.

51 Mona Gleason, “'They have a bad effect': Crime Comics, Parliament, and the Hegemony of the Middle Class in Postwar Canada,” in Pulp Demons: International Dimensions of the Postwar Anti-Comic Campaigns, ed. John Lent (Madison, NJ, 1999), 129-54. 
differed from traditional ones. ${ }^{52}$ Native Canadians have objected to how they have been portrayed as "savages" in school texts. ${ }^{53}$

Despite parental and other forms of social concern and controls, youngsters very often ignored or evaded restrictions. When he was seven, Farley Mowat claims, "I worked my way through a big, lavishly illustrated volume of Gargantua and Pantagruel and, though I must admit I did not understand much of the text, I certainly appreciated the marginal drawings of grotesque human beings engaged in things dear to the imagery of small boys, especially the representations of Rabelaisian farting and pissing."54 Helen Sigurdson's father "haunted" auctions, bringing home what her mother described as "junk." One item of interest to his children was a magic lantern with a set of French postcards. "The last one showed the man's back with two distinct handprints of flour on his shoulders." 55

Children secretly perused their parents' sex manuals and copies of "true confessions" magazines, and later such adult fare as Playboy. "In Grade 6," Shannon Stewart reported, "my best friend slipped me a copy of The Happy Hooker. I read the book as quickly as was humanly possible, in sheer terror that my parents might discover its hiding place. Xaviera Hollander's account of brothel life left me and a small group of suburban girls with enough knowledge of exotic and unlikely sexual acts that we would have been more interested in the Kama Sutra than the mandatory pink and blue pamphlets distributed in our Sex Ed classes."56

As well as reading, other forms of earlier media persisted from the nineteenth century into the twentieth. Children attended

52 Three books excluded from Surrey school classrooms are texts written for primarygrade youngsters: Rosamund Elwin and Michele Paulse, Asha's Mums (Toronto: Women's Press, 1990); Johnny Valentine, One dad, two dads, brown dads, blue dads (Boston: Alyson, 1994), and Leslie Newman, Belinda's Bouquet (Boston: Alyson, 1991); see Vancouver Sun, 22 June 2000, B1, B4.

53 Mea culpa. First Nations are harshly described in my two 1960s high school texts. Neil Sutherland and Edith Deyell, Making Canadian History, v. 1 \& 2 (Toronto: Gage, 1966; 1967).

54 Farley Mowat, Born naked (Toronto: Key Porter, 1993), 51.

55 Sigurdson, I Wanted You to Know, 11.

56 Vancouver Sun, 4 March 2000, E11. 
live theatre, vaudeville, church and Sunday school concerts, minstrel shows, and chautauqua sessions. ${ }^{57}$ What were called "medicine shows" always attracted youthful audiences. Joseph Wilder recalled "Professor" Sutton's visit to Winnipeg early in the century. On a makeshift stage lighted by oil pressure torches, there was a "free show with minstrels, black face comedy and fancy ladies who danced." At its peak "the professor came onto the stage" and pointed to "his display of bottles filled with tapeworms. With a pair of forceps he drew out yards and yards of one..." However, at a dollar a bottle, his "wonderful medicine will resist not only the ravages of tapeworm, but also cancer and fever." 58

Even such prosaic, even solemn, occasions as prayer meetings provided entertainment. In her diary, thirteen-year-old Christina Young noted almost weekly attendance at a Methodist mid-week meeting. On 25 April 1897, she wrote, "Lucy Mason and I almost always sit together in prayer meeting, and when we sing we try to drown each other out. Lucy and I sing about the same, but Virginia soars far above us." On 1 May she set the wider stage for us. "Before the meeting the men talked about the weather and the price of things. And who was likely to go in at the next election...After prayer meeting the young men hurried outside and stood waiting in the dark till the girls came out. Then each one that had a girl stepped up and asked to see her home.” 59

Live theatre, especially vaudeville combined with motion picture performances, persisted until after the Second World War. In the late 1930s, actor $\mathrm{Al}$ Waxman recalled that when "I was probably less than five, my parents took us to see Abbie's Irish Rose at the Royal Alexandra Theatre. We sat way up in the second balcony. So steep and up so high that it was scary, but I was on my daddy's lap, so I felt safe and excited. Mostly I remember being

57 Church concerts, called “Times” in Newfoundland and elsewhere, are vividly evoked in R. F. Sparkes, The Winds Softly Sigh (St. John’s: Breakwater, 1981), 99-102.

58 Joseph Wilder, Read All About It: Reminiscences of an Immigrant Newsboy (Winnipeg: Peguis Publishers, 1978), 64. In O Time In Your Flight (Madeira Park:

Harbour, 1979), 116-22, Hubert Evans evokes the excitement aroused by the visit of a medicine show to a small Ontario town at the turn of the century.

59 Mary Mckenzie (pseudonym), When I was Thirteen (Aylmer, Ontario: Aylmer

Press, 1979), 37, 43. 
surrounded by laughter, and that my parents were happy."60 Sandra Woolfrey remembers being taken, in the 1940s, "to two plays in the townhall. They were thrilling. One was a minstrel show. The novelty of the blackened faces and the banjo music was exciting. The other play featured a romantic looking young woman to whom a young man sang, 'Daisy, Daisy, give me your answer true'.,'61

Cinema was the century's first new popular medium. From the very first motion pictures, Canadian children clearly valued them above all other forms of popular culture. ${ }^{62}$ Angelo Branca recalled Vancouver's Bijou Theatre as it was before the Great War: "We used to pay a nickel to go in there, and with the nickel you got a ticket to go back next week, so you got in for two and a half cents, really." 63 A woman born at the turn of the century recalled viewing "Charlie Chaplin one-reelers. We even had skipping songs about him."64

Sometimes, "going to the picture shows" was family entertainment for many children, especially younger ones. It was "a big treat to go to the picture show with Mom and Dad." ${ }^{65}$ For Harvey Kirck, growing up in northwestern Ontario, his first motion picture was shown by a temperance organization in the basement of the local United Church, "a faded print of a tear-jerker called

60 Al Waxman, That's What I Am (Toronto: Malcolm Lester Books, 1999), 14.

61 Sandra Woolfrey, "Growing Up in Bloomfield: How I got Culture in the 40's and 50's,” County Magazine: The Magazine of Prince Edward County 18, no. 85 (Fall 1997): 21.

62 My subjective evaluation is confirmed, at least for American children, by an extensive investigation into the role of motion pictures in the lives of young people conducted by social scientists under the auspices of the Payne Foundation. The research, conducted between 1929 and 1933, is summarized in Henry James Forman, Our Movie Made Children (New York: Macmillan, 1933).

63 Daphne Marlatt and Carole Itter, eds., Opening Doors: Vancouver's East End (Victoria: Provincial Archives, 1979), 28.

64 See "Charlie Chaplin went to France..." in Edith Fowke, Sally Go Round the Sun: 300 Songs, Rhymes and Games of Canadian Children (Toronto: McClelland and Stewart,1969), 60. See also "Charlie Chaplin," in The Lore and Language of Schoolchildren, ed. Iona and Peter Opie (Oxford: Oxford, 1959), 108-10 for the worldwide use of various versions of this rhyme.

65 Canadian Childhood History Project (CCHP) interview. 
Ten Nights in a Bar-room.”66 Many rural youngsters had to wait until the National Film Board's rural circuit, begun during the Second World War, to see their first motion picture.

Most often, however, children and adults attended at different times. For over half of the century, for children "the good day was Saturday" because of the afternoon matinee at the local cinema. While they clearly enjoyed the features, the serials, and the cartoons, children most of all enjoyed matinees as a social experience. By the early 1920s matinees arrived at a pattern that persisted until television, videos, and parental concerns brought them to an end: one or two adult features together with various short subjects.

As matinees came to follow a similar pattern all across the country, so too did the movie-going script of Canadian youngsters. "For several years," wrote John Norris of his Nelson, BC, childhood of the 1930s, "Saturday was a very special day for my brother and me, not only because we were free of school, but also because the whole day from noon until bedtime followed a pleasurable routine- - walk to the centre of Uptown for an afternoon at the picture show, a streetcar ride home to one of our favourite suppers.” ${ }^{\prime \prime}$ In Sault Ste. Marie, in October, 1935, wrote Morley Torgov, "It is Saturday, lunchtime...the Saturday matinee at the Algoma Theatre begins in less than an hour. Burgess, my redheaded friend will soon be knocking at the door. There will be a dime for the movie, a nickel for a chocolate bar, and a couple of hours of re-enacting with Burgess that day's episode of the Tarzan serial after the show is over and we are let out blinking in the late afternoon sun."68

If over these years the fare changed-silent films accompanied by organ, orchestra, or piano music gave way to the "talkies," colour replaced black and white, and the technology of cartoons improved greatly - the children's response to the Saturday matinee did not. In an atmosphere of what one described as

66 Kirck, Nobody Calls Me Mister Kirck, 22.

67 Norris, Wo Lee Stories, 75.

68 Morley Torgov, A Good Place to Come From (Toronto: Lester and Orpen, 1974), 39. 
“disorganized bedlam," “they stamped their feet, went on an endless procession to the bathroom," hissed scenes they didn't like, "threw stuff over the edge of the balcony and at each other," and otherwise "did all the things you couldn't do at school."

Movies sometimes frightened their youthful audiences, and might even bring on nightmares. Watching Son of Lassie, Jean Little "had both hands tightly pressed over my ears, and I kept shutting my eyes and then opening them a slit only to squeeze them shut again...Suddenly one of the Germans raised his rifle and fired. With a spring, I was out of my front-row seat and under the stage, crouching among litter of candy wrappers. Now, with both eyes and ears as closed as I could get them, I was moaning 'Tell me when it's over. Tell me when it's over'.,69 “It was funny,” noted "Candice," because "during cowboy movies when the guys died, my sister would always think they were dead so we had to sit through the movie again to make sure they weren't."70 However, most children learned to know what to expect, looking forward, as one explained, to "the safe but delicious terror" brought on by certain movies. Sometimes they employed such mechanisms as closing, or partly closing, their eyes, covering their ears, or putting their heads down during the parts they both did and did not want to watch.

But there was sometimes a grim side to the matinee experience. "Anita" remembered, of a matinee in the late 1950s, "this creepy kind of man who sat beside me and kept putting his hand on my leg, just above the knee. I kept wriggling, trying to move further away. I was really afraid to yell out or even say a single word, except I started to cry. He said a really bad word, got out of his seat and disappeared into the dark."71 As was the case with other sexual assaults, children's fears of what they often did not know, or fear of in some way of being blamed, for what was

69 Jean Little, “I sat in Loews Theatre...'” in Too Young to Fight: Memories from our Youth During World War II, ed. Priscilla Galloway, (Toronto: Stoddart, 1999), 80.

70 Quoted in Lorraine Blashill, Remembering the '50s: Growing Up in Western Canada (Victoria: Orca, 1997), 107.

71 Quoted in ibid., 102. 
happening, meant that many, perhaps most, such attacks passed unreported.

Even if they seemed to pay them little conscious attention, children absorbed something of history and current affairs from the wider world displayed in films and newsreels. Films and newsreels also taught or strengthened racial, gender, ethnic, national, and class stereotypes. Blacks, whether American or as "natives" located elsewhere, were never taken seriously but seen as figures of fun or fear. ${ }^{72}$ Over the century films depicting wars at various times demonized native North Americans, Germans, Italians, Japanese, Russians, North Vietnamese, Chinese, Iranians, and Iraqis. In 1945, scenes of Nazi concentration and death camps, and of released prisoners-of-war who had been captured by the Japanese, deeply disturbed some youngsters. ${ }^{73}$ Such westerns as Little Big Horn portrayed Indians as vicious savages, and such adventure films as The Siege implied that many Muslims were terrorists. Movies also reinforced gender stereotypes. From Snow White and the Seven Dwarfs (1937) through to Mulan (1998), the heroines of Disney cartoon features were destined for a happy-everafter marriage. $^{74}$

Girls and boys looked at films and later at television in different ways, and movies thus added another dimension to emerging gender identities. Boys identified themselves with the leading male characters, especially when they were involved in vigorous activities: fighting, shooting, riding horses, and so on. When the male lead turned to romance, boys jeered. In their fantasies, and later in their play, boys saw themselves in the hero's role as he dealt with the villain. Girls identified with female stars in a more romantic way. They enjoyed the tender moments between romantic leads, and sometimes wept during scenes that were sad. They carefully studied the hairstyles and clothing of

72 Many of these caricatures are shown in clips in Spike Lee's film Bamboozled (2000).

73 See, for example, Joe Rosenblatt, Escape from the Glue Factory: A Memoir of a Paranormal Toronto Childhood in the Late Forties (Toronto: Exile Editions, 1985), 47-48.

74 See Kathi Maio, “Disney’s Dolls,” New Internationalist 309 (Dec. 1988), 12-14. 
attractive women. Girls disliked the noise made by boys during "love" scenes and tried to hush them. In their fantasies, girls saw themselves in a romantic relationship with the male lead.

During the years of strict movie censorship-from the late 1920 s to the 1970 s-movies were both less violent and less sexually explicit than later became the case. Daydreams then neither led to an explicit understanding of the grim realities of violent death nor, in male-female relationships, beyond dreams of hand-holding, embracing, kissing, and so on. The introductory vignettes dealing with Scream 2 and Star Wars suggest, however, that children have less difficulty with the subject matter of more recent films than adults feared.

The social value of the Saturday matinee and other shared movie experiences carried over into childhood discourse and play. A woman noted we "would get together and retell the movie with much arguing over the sequence of events." 75 In the case of a particularly good movie, a number of women reported, they "would spend the whole week reconstructing it with an effort to get the dialogue correct and facial expressions described accurately.",76 Boys built much of their play around activities (and stereotypes) they had seen in films, especially in war movies and westerns. In fact, the stereotyping was so strong that, as Judge Albert Scow reported, at the Alert Bay residential school he attended, children often "re-enacted some of the more dramatic scenes of the movie and of course we played cowboys and Indians. Everyone wanted to be a cowboy; nobody wanted to be an Indian." "77 As the opening vignette featuring Annie Mayes suggested, the coming of videos that one could play over and over again intensified the possibilities for the imaginative employment of movie events.

Movies sometimes served as a sort of job training. When he was about nine years old, Sammy Luftspring's father took him to his first boxing match, where he "immediately fell in love with the sport." After watching the excitement, including a victory

\footnotetext{
75 CCHP interview.

76 Ibid.

77 Quoted in J.R. Miller, Shingwauk's Vision: A History of Native Residential Schools (Toronto: University of Toronto Press, 1996), 281.
} 
procession, Luftspring, who went on to be a championship boxer, reported: "That was the night I decided on my life goal. I, too, would take a shot at becoming a king." Luftspring started to box before he was ten. He then attended the movies on Saturday "to study the previous week's main eventer from Madison Square Garden,” a regular feature of the newsreels of the day, often staying through three or even four performances of the program. "How fascinated, how hypnotized I could get...seeing on that screen an arsenal of ring techniques..."78 When actor Al Waxman saw The Jolson Story, he "couldn't leave the theatre. I sat and watched the next showing and the next, until the last showing that day. And then I came back every Saturday with a lunch that I had packed so I wouldn't have to leave the theatre until the last showing was completed." In all, Waxman saw the film "twenty-seven times...I bought all his records...I began to imitate him...that is, in front of a record player, playing his songs.",79

Not all children went to the Saturday matinee. Some stayed away through choice; they found the noise, and the press of so many children confined in a small space, uncomfortable or even frightening. Some families took up all of their youngsters' nonschool time with family chores. Other families objected to movies on religious, moral, or safety grounds, and forbade their children to attend them. ${ }^{80}$ "John" noted that the "only time we went to the theatre was to see the Coronation of Queen Elizabeth II. The pastor of our church went to the school; ...I guess he gave them permission to take the kids." ${ }^{81}$ Nonetheless, most children made it their business to have at least a rough idea of what was going on in the world of the feature film, the cartoons, and the weekly serials.

Radio was the century's second great new medium. In the early 1920s, crystal set radios, listened to through earphones, served as a novelty item for children and adults alike. With the

78 Sammy Luftspring, with Brian Swarbrick, Call Me Sammy (Scarborough: Prentice-Hall, 1975), 34-35, 43.

79 Waxman, That's What I Am, 35-36.

80 Seventy-six children died in a motion-picture theatre fire in Montreal on 9 Jan. 1927. Toronto Globe, 10 Jan. 1927, 1, facsimile reprint, in Toronto Globe and Mail, 9 Jan. 1999, D9.

81 Quoted in Blashill, Remembering the '50s, 92. 
addition of amplifiers, radios became an exciting centre of family rather than individual entertainment. Of himself and his childhood friend Glenn Gould, Robert Fulford observed: "We were vehemently part of the first and last radio generation, the people for whom radio was a central medium of communication...We were both born in 1932, just as the Americans and Canadians were clicking into the idea of national radio;... it became the center [sic] of our knowledge of the world." Fulford explained that a "large part of music came to Glenn through the radio...;for him it was radio and live performances, and records I think were in third place." 82

Most radio stations devoted the lunch, supper, and early evening hours to programs directed to family audiences. Parents usually controlled the choice of station. Families, "everyone sitting around in the living room," listened to "Don Messer," "The Happy Gang,” "Saturday Night Barn Dance,” and to hockey and baseball games. Robert Thompson recalled "Sports broadcasts that held you riveted to the set included the Joe Louis fights...and Hockey Night in Canada with Foster Hewitt."83 Many other families joined the Waxmans in listening to such American shows as " 'Lux Theater of the Air,' 'The Jack Benny Show,' 'Fibber McGee and Mollie,' 'Wayne and Shuster,' [and] all the serials: 'The Lone Ranger,' 'The Green Hornet,' 'Suspense,' 'Inner Sanctum.' So many trips into fun, fright and fantasy." ${ }^{84}$ Family members listened as they went about their tasks. Thus radio and doing the dishes became part of the routines in many families as parents and children listened together as they did this pervasive chore.

In the late afternoon and on weekends, some radio stations carried programs for children; "Audrey" reported that two "radio programs that we could not miss were 'Maggie Muggins' and 'Just Mary'.”85 “Little Orphan Annie,” “Dick Tracy,” “The Lone

\footnotetext{
82 Quoted in Peter F. Ostwald, Glenn Gould: The Ecstasy and Tragedy of Genius (New York: Norton, 1997), 64.

83 Robert H. Thompson, Penny Candy, Bobskates and Frozen Roadapples: Growing Up in the Thirties and Forties (Victoria: Orca, 1990), 69.

84 Waxman, That's What I Am, 14, 31.

85 Quoted in Blashill, Remembering the '50s, 87.
} 
Ranger,” and other children's programs on private stations had "clubs" that youngsters could join, usually in exchange for cereal boxtops or other proofs of purchase of the sponsor's product. In exchange, children received badges, secret codes, and other inexpensive paraphernalia, thus adding a new dimension to traditional youthful activities.

While many people, especially men, recall listening to championship boxing matches, especially those featuring the American Joe Louis, hockey was the most popular of radio sports. Harvey Kirck reported, “Our 'local' station was CJKL in Kirkland Lake, which carried CBC programs, including the Saturday night hockey games...Is there a middle-aged man anywhere who did not collect Bee Hive Golden Syrup hockey photos in his youth? I had a collection a couple of inches high, and right on top were Syl Apps, Gordie Drillon, and Bob Davidson-all glorious action pictures, with the players cutting in front to the camera, sticks low and poised, skates sending up a shower of ice that seemed to leap right out at you."86 A later generation collected hockey cards, initially distributed in bubble-gum packages.

While family radios became increasingly widespread in urban Canada through the late 1920s and 1930s, they were still rare in rural Canada. Battery radios were expensive and inconveniently took their power from "wet-cell" (or a combination of dry-cell and wet-cell) batteries. Since wet-cell batteries had to be recharged, involving either a windmill charger or a long trip to town, families rationed radio listening. Rural listening to distant stations also brought problems with static. Thus Roch Carrier's family radio "crackled like an egg that's cooking in a frying pan." 87 Nonetheless, rural listening patterns resembled their urban counterparts. In the 1930s, in the outport settlement of Ship Island, in Bonavista Bay on the northeast coast of Newfoundland, Walter

86 Kirck, Nobody Calls Me Mister Kirck, 19.

87 Roch Carrier, “I was eight years old on August 6, 1945...” in Too Young to Fight, ed. Galloway, 67. 
Carter joined other local boys at his uncle's home to listen to "The Adventures of Superman."

As small radio sets became widely available and increasingly inexpensive, especially after the development of transistors, older youngsters acquired their own. This change was accompanied by a rapid extension of commercial radio programming directly focused on the adolescent consumers. Although not the targeted audience, children joined teenagers in abandoning programs directed at wide audiences for those "hosted" by disc jockeys who played popular music, often in a "top 40s" format. In Toronto, radio station CHUM made a local star out of "Jungle” Jay Nelson, as did Vancouver's CJOR of "Red” Robinson, who in 1957 interviewed a visiting Elvis Presley for his audience. In Windsor, "the" station to listen to was CKLW and, in Montreal, CFCA.

Jeanne Beker recalled that her "palm-sized, bright orange and gold radio, with the brand 'Hollywood' emblazoned across the front, was one of the most fascinating and liberating things I'd ever owned. It transported me to worlds outside the confines of my safe, suburban bedroom, where cute deejays talked to you under the covers, late into the night...I was 10 years old when I got that radio. By the time I was 12, I knew every pop song by heart. My six-transistor had become a constant companion, a valuable ticket to life beyond Grade 7." ${ }^{\text {"9 }}$ Cynthia Good explained that through radio there was a "pre-Beatles me and a post-Beatles me."90

Prompted by their radio (and, later, television) listening, some youngsters, as well as their teen-aged siblings, also listened to their favourite singers on records, a practice made much more widespread with the introduction in the 1950s of inexpensive 45rpm records and record players. Youngsters quickly acquired their own records of current pop favourites such as Presley, the Beatles, through to the compact discs of Rap stars of the 1990s. In August, 1966, Shelley Fralic was "barely 13...My best friend Debbie and I are sitting on my bedroom floor...On the table, a

88 W alter C. Carter, Never a Dull Moment (St. John's: Creative Book Publishing, 1998), 19-22.

89 Vancouver Sun, 26 Dec. 2000, F12.

90 On “Vinyl Café,” CBC 2, 27 Jan. 2001. 
transistor radio turned up loud...It is everything. My connection. To the music, to the world, to the voices of my generation.” Fralic won a ticket to go to Seattle to see the Beatles. "To be honest, I don't remember much else about the trip. (Except the screaming, of course....And to this day, my mother still can't believe that she and all those other parents let their tender baby girls get on a bus going to another country with a 20-year-old rock jock with a reputation)." 91

In her study of women in her 1961 class at R.H. King Collegiate in Scarborough, Ontario, Maggie Siggins noted a central characteristic of popular music of her school years but one that also applies to much of the twentieth century. For youngsters of the 1950s and 1960s, she explains, their "music world, the beat we danced to in the gym Friday nights, was entirely a masculine phenomenon... That girls could be the originators, the creators of any type of music never entered our heads." 92 It was not until the 1970s that a significant number of women, including Connie Francis, Anne Murray, and Peggy Lee, began to appear amongst the higher rankings on the popular music charts.

In the 1950s television gradually replaced radio as the centre of family entertainment. ${ }^{93}$ As television reception spread across Canada-often first from nearby stations in the United States-many families began to spend time, including mealtime, together in front of their black-and-white set. They watched the news, "Howdie Doodie," "Highway Patrol," "George Gobel," "wrestling," and, as the CBC network came to their community, the televised version of "Hockey Night in Canada." Together, families watched Elvis Presley and then the Beatles on the "Ed Sullivan Show." Television news programs took more children into the wider world than had other media. Watching supper hour news programs ended such sheltering from violence as movie

91 The disc jockey who organized the contest and trip was Fred Latremouille. Vancouver Sun, 21 Nov. 1999, E5.

92 Maggie Siggins, In Her Own Time: A Class Reunion Inspires a Cultural History of Women (Toronto: HarperCollins, 2000), 558-59.

93 See Doug Owram, Born at the Right Time: A History of the Baby Boom Generation (Toronto: University of Toronto Press, 1996), 87-93, 152-55. 
censorship had tried to accomplish. Depictions of natural disasters, American civil rights marches, and political demonstrations in all parts of the world, and of wars in Vietnam, the Middle East, and Africa opened many youngsters' eyes to the brutality and violence that has always been a characteristic of human relations.

As it had been earlier with the Saturday matinee, it was essential to know what went on in the popular programs in order to take part in peer-group discourse. Those children without television visited those who did have it. The ingenious efforts made by others to watch testify as to the importance of knowing what went on. In the early 1950s, Murray McLauchlan's family did not have a television but neighbours across the street did. The McLauchlan children sat in their glassed-in sunporch, telephoned the neighbour's children, "and we'd all sit on the daybed listening to the sound on the telephone as we watched through the window."94 In 1957, when she was about ten, Catherine Macleod's family emigrated from Scotland and settled first in a trailer park in Fruitland, near Hamilton, Ontario. She wrote that before "we got our own television, my brother and I would slip out on moist summer nights to perch ourselves on a neighbour's trailer hitch and watch" whatever the Turners were watching, all to the sounds of crickets. "If the neighbours knew our faces were pressed to their window they never let on."95

Some programs for children made life-long impressions on their youthful watchers. Every child who could do so watched the "Mickey Mouse Club” and "Captain Kangaroo," both now fondly recalled. Nick Finnamore, of Arthurette, NB, reported that, on reading the obituary of Robert Homme, "Childhood visions of the Friendly Giant in his suit, Jerome with his head in the window and Rusty in his bag passed through my mind. I could hear the Friendly Giant's gentle voice offering 'a little chair for one of you, an armchair for two or more of you to curl up in, and for someone

94 Murray McLauchlan, Getting Out of Here Alive: The Ballad of Murray McLauchlan (Toronto: Viking, 1998) 24.

95 Catherine Macleod, Waking Up in the Men's Room: A Memoir (Toronto: Between the Lines, 1998), 20. 
who likes to rock, a rocking chair in the middle'."96 Of Ernie Coombs as "Mr. Dressup," Karen Chee wrote, "He taught me English when I only knew how to speak the Cantonese of my parents. He taught me creativity and imagination...Along with my parents and 'Sesame Street,' Mr. Dressup nurtured me into becoming a healthy, happy child. He represented stability in my world."

A multiplicity of channels and the increasing numbers of families owning more than one television set gradually separated children and adults into separate audiences. Some programs, however, were so popular that both parents and children made a point of keeping up with what went on in them. They puzzled over the final couplet in the theme song of "All in the Family" ("Gee our old LaSalle ran great...”) and the various levels of meaning in "The Simpsons."

From the late 1950s onward, however, children's viewing was dominated by commercial television. Many stations began to schedule special cartoon programs for children, especially on Saturday mornings. By the end of the century children with access to cable television could find cartoons at virtually any time of the day, but especially before and after school. Increasingly, the most popular of these programs were tied to commercial products that they advertised aggressively.

In the latter years of the century, the appearance of video cassettes and the video cassette recorder would turn cinema into family entertainment analogous to the earlier days of radio and then television. Parents rented or bought tapes of movies deemed suitable for children, who then watched them over and over again. Saturday matinees virtually disappeared as younger children watched television cartoon programs videos, alone or with friends. Their older siblings turned to "adult" films, especially those featuring "special effect” and considerable violence. Although

96 Maclean's Magazine, 12 June 2000, 8.

97 Vancouver Sun, 21 Sept. 2001, A15; some adults who watched Coombs as children appear in "Ernie Coombs: Tales from the Tickle Trunk," a program in the CBC series "Life and Times." 
adolescents often rented the latter, most preferred to see them on the large screen in the company of friends. By the end of the century, cinema permeated the lives of children more completely than ever before.

In the final years of the century, computers, and especially computer games, e-mail "chat" rooms, the internet, and cellular telephones added themselves to the array of media enjoyed by the young. For some young people, and especially those who did not fit into a school hierarchy, the internet provided an alternative social network. Chad Skelton explained that he “didn't have the school spirit to be on student council, the muscles to make the football team or the artistic flair to try out for the school play." He spent his time "with my two or three good friends ...[and] hours every week online." There, he "found people who shared my interests ...The online community became my circle of friends, a place where I fit in, an oasis from the intense stress and loneliness of high school. Once every few months a bunch of us would...meet for dinner. In short, my online life made my highschool years bearable." 98

In 2000 and 2001, a study funded by the federal government and conducted by the non-profit Media Awareness Network of Ottawa surveyed over a thousand Canadian families and, later, thousands of children and youth as to how the latter use the internet. These surveys revealed a wide discrepancy between what parents believed about their children's use of the internet and how the latter actually used it. The fact that many youngsters reported visiting pornographic sites and adult chat rooms alarmed at least some of those who examined the findings of the studies. Others were less concerned. Is the fact that boys are far more likely than girls to visit adult sites a matter of new concern, or but the most recent manifestation of the perennial interest that boys, even quite young ones, have always displayed in sex? This and other aspects of the topic are certainly worthy of study, and parents, teachers,

98 Vancouver Sun, 29 May 1999, E5-6. 
researchers, and social commentators will undoubtedly return to it in the new century. ${ }^{99}$

My conclusions about the role played by the media in the culture of Canadian in the twentieth century are tentative ones. Clearly, books, magazines, radio and television programs, the internet, and, especially, movies played a major role in children's lives. Some roles were within the conscious or unconscious intentions of the adults who created and supervised the media. Although certain things children read may have undermined those gender, class, racial, ethnic, political, or national stereotypes that pervaded popular culture, most media ceaselessly reinforced them. Nonetheless, both on their own and as members of their peer group, children also employed media in ways of their own devising to meet needs arising out of youthful culture. In "cowboys and Indians" those playing the latter insisted on winning some of the time, and many a Barbie, imagined as a movie heroine, had simulated sexual intercourse with a star represented by Ken. Further, although youngsters valued these media mostly for their entertainment, willy-nilly they also informed them about the world in which they lived.

Second, this paper suggests some of the influence on children that flowed from the human voice. Since it was the medium of family, school, congregational, and playground discourse, what has been said here only hints at the importance of the spoken word in the lives of the young. It but touches on voices raised in song. Many of my informants told me that they could still hear the voices of parents, grandparents, and teachers both in their minds and in their dreams. Perhaps "the voices of childhood" deserve a separate investigation.

99 The study and comments about it are summarized in the Toronto Globe and Mail, 5 Jan. 2002, F6-7. The study itself can be found in Media Awareness Network, "Young Canadians in a Wired World,” www.media-awareness.ca 
Finally, an observation triggered by the historian of colonial America, Bernard Bailyn. In an influential interpretive essay, Bailyn defined education "not only as formal pedagogy but as the entire process by which a culture transmits itself across the generations." 100 Like other historians of education, I enthusiastically quoted Bailyn's definition to students over the years. Also, like my colleagues, I made but limited use of Bailyn's formulation in my own research and writing. Although I have described here how some popular elements in the process of cultural transmission were looked upon by Canadian children, we really know little about how their outlook on their culture was actually affected by media.

Writer Joy Kogawa was born in Vancouver in the mid-1930s. In 1942, she with other Japanese Canadians was interned. "In Slocan I read the Book of Knowledge and also the Book of Golden Deeds. There was a poem in one of them by 'Author Anonymous' that somehow seemed to make things possible for me. I aspired to have one poem published before I died.” In contrast to modern youngsters raised on Bugs Bunny and Road Runner, she "was lucky enough to have been exposed to both Japanese folk stories and Christian stories in the Anglican Church. I went to a whole range of Sunday schools. The Power Rangers teach that might is right. It makes me weep." "101

Since they are widely shared, we have to take seriously the sorts of concerns embedded in Kogawa's comparison between her experience of the media and that of present-day children. While I'm not sure that weeping is in order, probably some vigilance is. Nonetheless, about the only firm judgment I will venture is that, so far, none of the media has had anywhere nearly as much negative effect on the young as was foretold in the warnings of their critics.

100 Bernard Bailyn, Education in the Forming of American Society: Needs and Opportunities for Study (New York: Vintage Books, 1960), 14.

101 Lisa Birnie Hobbs, “Joy Kogawa: Medieval Nun in Search of the Soul,” Western Lights: Fourteen Distinctive British Columbians (Vancouver: Raincoast, 1996), 102-3. 